\author{
Patryk Słowiński \\ Zachodniopomorski Uniwersytet Technologiczny w Szczecinie \\ E-MAIL: psd@02.pl ORCID: oooo-ooo1-8391-7292
}

\title{
Opowiadanie obrazem: autorski plakat społeczny
}

\begin{abstract}
STRESZCZENIE
Celem artykułu jest przybliżenie założeń teoretycznych zjawiska, które określić można jako „plakat społeczny”. W pierwszej części pracy opisuję początki, źródła oraz historyczny kontekst powstania i funkcjonowania tzw. Polskiej Szkoły Plakatu, która na przełomie kilku dekad XX wieku budowała znaczenie plakatu, nie tylko jako dzieła artystycznego (z wyraźnie widoczną funkcją estetyczną), ale również jako wytworu o silnym oddziaływaniu społecznym. Druga część tekstu ma zdecydowanie bardziej osobisty charakter. Przedstawiam w niej tematykę swoich plakatów oraz zdarzenia i impulsy, które skłoniły mnie do jej podjęcia. Decydującymi elementami w doborze tematów jest dla mnie społeczeństwo i zachodzące w nim zmiany. A plakat to, moim zdaniem, najbardziej ludzka forma przekazu myśli w przestrzeni miejskiej, będąca jednocześnie ważnym głosem w „walce ulicznej”.

SŁOWA KLUCzOWE: plakat społeczny, oddziaływanie społeczne, plakat jako forma wyrazu
\end{abstract}

Pojęcie plakatu pozornie wydaje się nieskomplikowane. Najprościej mówiąc, plakat to wyrób poligraficzny zaliczany do akcydensów - duży arkusz papieru (o formacie co najmniej A2) zawierający informację wyrażoną $w$ formie graficznej, w której dominuje funkcja impresywna - skłaniająca odbiorcę do konkretnych zachowań. Autorzy Słownika języka polskiego pod redakcją Witolda Doroszewskiego, tworząc definicję plakatu wskazywali na jego związek z reklamą, ogłoszeniem, hasłem i podkreślali jego synonimiczność wobec afiszu, ogłoszenia i obwieszczenia. Zwracali także uwagę na fakt, że podstawowe środki wyrazu są plastyczne. Komunikat jest „ujęty w artystyczną szatę drukarską, malarską lub graficzną” i dalej: „Plakat działa obrazem lub rysunkiem, tekst jest w nim czymś co najwyżej uzupełniającym, stąd winno go być jak najmniej" (Doroszewski, online). Pierwsze plakaty były ogłoszeniami ilustrowanych książek sprzedawanych w prenumeracie. Na pomysł reklamowania ich w formie plakatu wpadli w XIX wieku paryscy księgarze, którzy dzięki temu mieli nadzieję na zwiększenie swoich dochodów (Lenica, 1952, s. 35). Nie bez kozery więc Jan Lenica twierdził, że „plakat jest dzieckiem kapitalizmu” 
(Lenica, 1958, online). Plakat jest wszelako - pozostając medium ulicznym i społecznym - także artystycznym gatunkiem grafiki użytkowej, w którym funkcja estetyczna dominuje nad impresywną oraz ekspresywną (nie wycisza tych funkcji, lecz je wspomaga). Jest to forma wypowiedzi pozwalająca bardziej niż inne plastyczne formy artystycznego wyrazu na podejmowanie istotnych tematów oraz snucie poważnych refleksji ze względu na cechującą ją wielowarstwowość, aluzyjność i niedopowiedzenia. Szczególną zaletą artystycznego plakatu jest jego zdolność do nawiązywania interakcji z odbiorcą, rozbudzania jego aktywności przez wyrafinowane chwyty intelektualne.

\section{Polska Szkoła Plakatu}

Za pierwszy polski plakat artystyczny uważa się powstały w 1899 roku, wykonany techniką litograficzną, afisz informujący o odczycie Stanisława Przybyszewskiego, połączonym z przedstawieniem dramatu Maurycego Maeterlincka Wnętrze (Dziewczynka za oknem)1. Już ten pierwszy artefakt oprócz - właściwej afiszom - funkcji informacyjnej oraz impresywnej ma funkcję estetyczną, która przy uważniejszej analizie wysuwa się na pierwszy plan. Nastrój plakatu oraz napięcie wyrażone przez formę plastyczną przełamuje pragmatyczną funkcję informowania o odczycie oraz przedstawieniu teatralnym i staje się „,artystycznym komentarzem do zaborowej rzeczywistości” (Giżka, 2007), nabiera cech plakatu politycznego i społecznego.

Po odzyskaniu niepodległości twórczość polskich plakacistów rozwijała się coraz bardziej dynamicznie. W 1922 roku w warszawskiej Szkole Sztuk Pięknych pod kierunkiem Władysława Skoczylasa utworzona została pracownia grafiki, w której od 1924 roku uczono liternictwa oraz projektowania graficznego. W 1926 roku na tej uczelni powołano do życia Pracownię Grafiki Użytkowej, która funkcjonowała pod kierunkiem Edmunda Bartłomiejczyka. W tej Alma Mater doskonalili swoje talenty między innymi Eryk Lipiński i Henryk Tomaszewski - wybitni plakaciści.

W 1926 roku na Wydziale Politechniki Warszawskiej utworzono Pracownię Grafiki Użytkowej, gdzie między innymi młodych adeptów sztuki uczono projektowania plakatów. Ta praca dydaktyczna niewątpliwie legła u podstaw sukcesu Polskiej Szkoły Plakatu, jakkolwiek sam ten termin jest niedoskonały i nieprecyzyjny. Najczęściej używa się go na określenie fenomenu, który pojawił się w polskim plakacie w latach 50. i rozwijał się aż do lat 70. XX stulecia

1 Nr inw. MPW.Pl.17161/1, Muzeum Plakatu w Wilanowie, oddział Muzeum Narodowego w Warszawie. Nabyty 7 listopada 1973 od Joanny Studzińskiej z Paryża. Zakład Litograficzny „A. Pruszyński”, prowadzony w 1899 r. przez następcę i syna Aureliusza - Zenona Pruszyńskiego. Lit. barwna, pap., $57,5 \times 12$. 
(zob. Giżka, 2007). Za jego autora wielu historyków sztuki uważa Jana Lenicę, który w 1960 roku napisał o Polskiej Szkole Plakatu w artykule opublikowanym w 88 numerze szwajcarskiego czasopisma „Graphis”. Nie sposób wskazać jednoznacznie atrybuty wyróżniające artefakty należące do tej Szkoły ze względu na bogactwo technik oraz zróżnicowanie osobowości twórców. W ciekawy sposób - i stosunkowo trafny - czyni to Sylwia Giżka:

Wspólny mianownik to być może jedynie wspomniana na wstępie aluzyjność, umiejętność wykorzystania każdego tematu, by mówić o Polsce, bądź o ludziach w Polsce. Plakat polski okresu PRL jest zdecydowanie humanistyczny, nastawiony na widza, to widz jest tu bohaterem, a nie reklamowane wydarzenie czy produkt, jak to miało miejsce w mistrzowskich przedwojennych plakatach handlowych. Dodatkowym wyróżnikiem jest indywidualność twórców, eksponowana bez skrępowania i bez ograniczeń wynikających z teoretycznych zasad sztuki reklamy wizualnej. Napięcie przebiega między twórcą a widzem i paradoksalnie, sam plakat jest tu tylko pięknym medium, pośrednikiem, czy zapiskiem tej rozmowy, swego rodzaju czarną skrzynką" (Giżka, 2007).

Trudno się nie zgodzić z tezą, że oderwanie od merkantylizmu, nastawienie na odbiorcę i poruszanie ludzkich spraw stanowi istotę Polskiej Szkoły Plakatu i rozstrzyga o jej wyjątkowości.

Szczególną rolę w powojennej historii polskiego plakatu odgrywały zamówienia na plakaty filmowe, a później - w latach 6o. - teatralne. Swoją drogą przed wojną cenione były i miały wysoki poziom graficzny plakaty handlowe - filmowe zaś nie były wykonywane przez artystów i cechowały się tandetą. Powojenne polskie plakaty filmowe są dziełami sztuki i nierzadko arcydziełami komunikacji. Ich twórcom udaje bowiem w sposób syntetyczny uchwycić istotę filmowego przekazu i wyrazić go w graficznej formie. Mimo stylistycznej różnorodności, wspólną cechą wymienionych plakatów jest swoisty antyestetyzm, oszczędność, dążenie do syntezy, czystość i lapidarność, skróty pojęciowe, czytelność wypowiedzi plastycznej, a nierzadko metaforyczność.

Dziś w czasach tandety, będącej skutkiem komercji oraz powszechnego dostępu osób niemających odpowiedniego wykształcenia plastycznego do narzędzi ułatwiających projektowanie, nadal powstają w Polsce wybitne plakaty, których twórcy sięgają do najlepszych światowych wzorców. Jednym z wybitnych współczesnych polskich plakacistów jest Sebastian Kubica autor między innymi plakatu zatytułowanego Fukuda in memoriam poświęconego twórczości genialny japońskiego plakacisty Shigeo Fukudy. 


\section{Mój plakat społeczny - proces twórczy to walka}

Tematy moich prac są wynikiem osobistych przemyśleń na temat kondycji człowieka, odwołują się do traumatycznych wydarzeń, są zapisem odczuć związanych z doświadczaniem własnej tożsamości. Tematy moich prac ewoluowały i rozwijały się i tworzą dziś spójny, zwarty cykl. Wynikają głównie z moich zainteresowań, wykorzystuję własne obserwacje medialnego świata, zbieram informacje i przetwarzam je we właściwy sobie sposób. Poruszam tematy, które uważam za ważne. Kreuję dzięki nim specyficzną przestrzeń, w której wyrażam swoje obawy i zainteresowania. Najbardziej interesują mnie aktualne zjawiska zachodzące we współczesnej sztuce. Staram się być na bieżąco z nowymi inicjatywami i wydarzeniami. Fascynują mnie twórcy $\mathrm{z}$ różnych dziedzin, poszukuję inspiracji w twórczości Egona Schiele, Francesco Clemente, dadaizmie, art brut, typografii i kaligrafii.

Mój proces twórczy zaczyna się od przygotowywania szkiców i rysunków. Często te pobieżne szkice, zainspirowane sytuacją czy wydarzeniem, są wstępną formą wypowiedzi. Problemy, z którymi zmagam się pracując nad plakatami budzą we mnie przemyślenia, często budowane „reserchem” tematycznym. Dopiero po jakimś czasie, kiedy już powstanie ogólne założenie, rozpoczynam pracę nad kompozycją, przygotowuję wstępne zarysy. Na tej podstawie wykonuję później próbki materiałów, z których powstaną grafiki. Tworząc je skupiam się na sile ekspresji, dopuszczam rolę przypadku, szukam nowych rozwiązań fakturowych. Proces twórczy to dla mnie walka pomiędzy chęcią impulsywnego działania, pod wpływem emocji, wykorzystywania roli gestu a działaniem świadomym i kontrolowanym, opartym na dokładnym wyobrażeniu efektu końcowego. W swoich działaniach i pracach staram się otwierać na świat i jego problemy. Zajmuję się tematami, które wynikają z moich fascynacji i opracowuję je, szukając własnych środków wyrazu. Mimo to dostrzegam, że pewne zależności między swoimi pracami a dokonaniami innych twórców. Nie da się tego uniknąć, jest to niewątpliwie wynikiem nieustannego obcowania z pracami twórców, których cenię. Moje kompozycje graficzne wynikają jednak przede wszystkim z moich osobistych zainteresowań, obserwacji codzienności, zbierania informacji pochodzących ze świata i mediów. Analizuję bodźce atakujące nas z różnych stron. W swoich pracach wiążę tematykę wojny z grą, zabawą, masową rozrywką. W czasie kształtowania tematu, jak i w momencie powstawania prac często wykorzystuję komputer oraz inne multimedialne narzędzia. Bardzo lubię mieć bezpośredni kontakt z materią, dlatego większość rzeczy najpierw powstaje manualnie, a dopiero później digitalizuję swoje szkice. $\mathrm{W}$ ten sposób powstają prace technicznie i tematycznie zróżnicowane. 
Pomimo inspiracji nie widzę punktów wspólnych moich prac graficznych $\mathrm{z}$ koncepcjami innych twórców. Jestem przekonany, że każda próba kreacji jest wytwarzaniem rzeczy nowych i znamiennych tylko dla jednego autora, choć dostrzeganie przez odbiorców punktów wspólnych między twórcami jest nieuniknione. Każdy przetwarza rzeczywistość na swój własny, niepowtarzalny sposób, ale problemy i emocje, które interpretujemy, są zawsze te same. Wolność artystyczna to możliwość krzewienia światopoglądu, lecz nie przez narzucanie go innym, a nawiązywanie dialogu. Sądzę, że w projektowaniu i w sztuce nie ma granic. Jedynym ograniczeniem jesteśmy my sami. Sztuka i projektowanie to dla mnie hermetyczny świat. Wolę myśleć o sztuce i projektowaniu jedynie w kategoriach potrzeby tworzenia, jako o czymś, co artysta tworzy przede wszystkim dla siebie, na użytek własnego poznania. Mój wybór był intuicyjny, zacząłem szkicować to, czego nie potrafiłem wykrzyczeć. W przypadku prac, które prezentuję, dynamika wypowiedzi i ekspresyjność gestu posłużyły mi do interpretacji emocji, które odnoszą się do stanów wewnętrznych związanych z poruszanymi problemami.

\section{Moje plakaty oraz ich tematyka}

\section{Emigracja}

Temat ten pojawił się w mojej świadomości z powodu umiejscowienia geograficznego. Żyję w strefie przygranicznej, $20 \mathrm{~km}$ od granicy z Niemcami. Tu wciąż wyczuwalne są tęsknoty z czasów „żelaznej kurtyny”, żywe jest wspomnienie nadziei i „złotych interesów” z lat 90. XX stulecia i obserwuje się współczesność „miasta straconych szans” - wyjazdów i powrotów; rozmów zaczynających się od pytania - na które nie zawsze łatwo znaleźć odpowiedź - „gdzie mieszkasz?”. Pytanie, które sobie zadałem czy miejsce dla tych ludzi, z którymi rozmawiałem ma sens. Zaskakujące jest to, że nie miało nigdy ani to gdzie żyją teraz, ani to gdzie żyli wcześniej, jak i to do którego wracają. Nie wykorzystywali go do wzbogacania własnej tożsamości przez kulturę i sztukę, lecz liczyła się dla nich wartość egzystencjalna. Często ta, która nie była wartością pierwszoplanową dla tych co zostali. Czy zatem emigracja ma związek z kulturowością? Myślę, że nie. Smutne, ale jakże utwierdzające, jaka jest dla większości piramida potrzeb.

\section{Filia}

Próba obserwacji władzy, przymusu i walki ze wszystkim, co łączy się z wykorzystywaniem seksualnym, tworzy ofiarę, zmusza do cierpienia. Obserwacja, której obiektem są nie tylko ludzi, ale także zwierzęta. Przyzwolenie społeczne widać w mediach przez brak reakcji na okrucieństwo, emocjonowanie 
się bestialstwem. W moich notatkach, szkicach pojawiało się wiele wątków tego jakże szeroko pojętego problemu. Jednak ustalenie ofiary, a raczej formy, na której spełnienie ma się wydarzyć jest dla mnie tym punktem zwrotnym. Pragnę podjąć dialog w zatrzymaniu kadru, który jest tą ulotną chwilą tuż przed, często przysłoniętą samym aktem.

\section{Bezrobocie intelektualne}

Zainspirował mnie aspekt „pokolenia wyższego” - dwie lewe ręce przeintelektualizowane, niechęć do zmian. Apatia czy obojętność. Osobiście kojarzy mi się częściowo z latami 7o. Nihilizm i chęć destrukcji. Takie miałem początkowe wrażenia po rozmowach i obserwacji. Absurdem okazał się mój tok myślenia, współczesne bezrobocie intelektualne to dobrowolne odcięcie się od otoczenia, bodźców, eutanazja potrzeb, wszystko to na rzecz spełnienia samego siebie. Egoizm można by rzec, lecz jest to zwykłe próżne marnotrawstwo.

\section{Biurokracja}

Moja codzienność: wypełnianie dokumentów - Orwell na żywo. Czy jestem trybikiem tej machiny nonsensu? Dokumenty, papiery, byle by tylko był przysłowiowy spadochron $\mathrm{w}$ razie komplikacji, gdyby osiągniecie celu było nagle ryzykowne. Marnotrawstwo energii i drzew, marnotrawstwo czasu i ludzi... tylko na rzecz wyimaginowanej rzeczywistości. Ten temat jest dla mnie próbą nawołania do działania przeciwko temu. Czy możliwe jest, by maszyna stanęła?

\section{New shark}

Bliskość tematu z racji pasji sportów wodnych, obserwacji akcji, na przykład w Maroku co tydzień sprzątanie linii brzegowej przez hipisów i surferów. Czy już jemy plastik czy jeszcze uciekamy? Na wykładzie, jaki miałem przyjemność wygłosić na Fashion-Expo opowiadałem o nieobliczalnej wartości odpadów jakie lądują do wód co roku. Nie chodzi tu tylko o aspekt rekreacyjny, czy fauny i flory, ale kwestii tego, że nasza alternatywa kulinarna będzie konkurowała $\mathrm{z}$ plastikiem w swoim środowisku. Według ostatnich obliczeń w 2050 roku ma być tyle samo ryb co śmieci. Czy na pewno chcemy tak dewastować, czy musimy korzystać z takiej liczby opakowań? Czy nie ma już alternatyw na nasze lenistwo? 


\section{Kariera}

Temat powstał na podstawie doświadczeń w pracy w korporacjach. Czy musimy nieustannie dążyć do wykazywania się? Czy właściwe jest ciągłe dążenie do ulepszania? Może należałoby zatrzymać się na poziomie: „dobrze”. Jeśli coś działa, po co to udoskonalać? Po co tworzyć problemy? Inspiracją był też kwestia wytwarzania współczesnych produktów i postarzania ich. Mechanizm nadrabiania dodatkowych sztucznych celów, by zawsze być w poczuciu spełnienia. Niekoniecznie obowiązku, lecz emocjonalnej satysfakcji, która pobudza do dalszego brnięcia w wyżyny piramidy złudzeń jakie sami sobie wyobrażamy. Osiąganie to proces. Nie sposób się uwolnić z wiru walki o szczeble. Z mojej obserwacji wynika, że jesteśmy od dziecka skazani na walkę o jakieś osiągnięcie. Czy potrzebne nam to poczucie? Czy istnieje możliwość innej formy niż taka, jaka nieświadomie jest nam wpajana? Wiem, że nie odpowiem jednym obrazem na tak wiele złożonych pytań, ale podjęcie tego tematu jest dla mnie potrzebą zabrania odbiorcy parę sekund $z$ tego wyścigu na rzecz stworzenia wątpliwości w nim nad sensem istnienia.

\section{Klan}

To temat, który pokazuje „siłę ołowiu” od Hell Angels aż po gangi, klany, czy lokalne grupy w kartelach. Czy to może solidaryzować? Obserwując różnego typu działania masowej przemocy w grupach, zastanawiała mnie potrzeba przynależności jednostek względem drugich. Dlaczego ów ołów tak zbliża. Czy następstwo, czyli okrucieństwo dodaje splendoru i tym samym pozwala uleczyć kompleksy? Nawiązałem do archetypu wizerunkowego który może się kojarzyć jako jeden z bardziej znanych grup przemocy. Poszukiwałem odpowiedniego koloru, lecz nie chciałem użyć czystego połączenia, zatem nawiązałem pośrednio z oznaczeniem, próbując ostrzec przed działaniem.

\section{Love}

Miłość sprzedana, kupiona, zużyta... to element wiążący. Czy miłość może być wyeksploatowanym produktem? Czy samotność to stan przejściowy? Zaciekawiła mnie forma, jaka się zmienia w relacjach międzyludzkich. Przy użyciu współczesnych mediów, to co 10, 20, 50 lat temu było niestosowne teraz jest pomijane wzrokiem niczym kolejna reklama. Kolejna osoba, a nie osobowość. Nie dokonanie, lecz forma dla formy tylko dla złudzenia uczuć. Czułe słowa stają się na tym poziomie już tylko intruzem, który leci za pożywką. Te spostrzeżenia spowodowały, że poczucie produktem nieświadomym jest na poziomie codzienności. Moja próba metafory nawiązania do zachodzącego zjawiska ma na celu wzbudzenie dyskusji, staniem się zaczepką do codzienności. 


\section{Kreatywność}

To wynik obserwacji wszelkich działań kontrolowanych. Dla mnie gdzieś utkane w socjalizmie, a na pewno działające do teraz. Marzenie jednostki o indywidualizmie, a realność wygląda inaczej. Kreatywność jest dla mnie tak samo absurdalna jak pokój. Oba te znaczenia nie funkcjonują. Kreatywność bez bodźców zewnętrznych nie istnieje. Mijamy codziennie tysiące obrazów, zapachów, dźwięków. Zostawiają w nas ślady, które tak naprawdę są wyimaginowane ręką, która porusza nasz mózg. Rozbicie obiektów tworzących obraz jest dla mnie synonimem wieloskładowego problemu budowanego na rzecz całości. Jest to dla mnie mroczna teoria, dlatego użycie koloru jest bardzo powściągliwe.

\section{Rewolucjonista}

Jeśli jest niemoc, to jest rewolucjonista... Już tylko sam w sobie wewnętrzny bunt. Sam mogę napisać, wykrzyczeć... w próżnię. To potrzeba z głębi. Myślę, że każdy choć raz znalazł się w sytuacji, która stała się dla niego absurdalną abstrakcją. Czy można z tym walczyć? Sukcesu nie odniesiemy, ale z pewnością satysfakcję z uwolnienia gniewu, sprzeciwu. Sytuacji takich nie musiałem szukać, dotykają mnie na co dzień, zazębiając się tworzą jedną wielką maszynę niczym z Orwella. Moja decyzja to wysoki kontrast i dziki kolor dla określenia emocji rządzących.

\section{Wyzwolony}

To złudzenie wolności to sen na jawie, to wrażenie możliwości. Nie ma wolności. Nie ma samodzielności, indywidualne próby przejawów walki znikają z prędkością zapalonej zapałki. Mylne poczucie jednostki. Spostrzeżenia wynikają z przeprowadzonych rozmów, obserwacji przejawów protestów, które wiodące niewidzialną ręką bardziej walczą o satysfakcję i spełnienie, niż o rzeczywistość. Moja decyzja względem estetyki wynika z faktu jak duże wrażenie robi na mnie bunt mas protestujących za tym co każe ręka.

\section{Zakończenie}

Istotą społecznego plakatu jest komunikatywność. Kiedy w mojej świadomości pojawia się idea, która domaga się tego, żebym podzielił się nią z innymi ludźmi, szukam środków wyrazu pozwalających na przekazanie jej odbiorcom bez względu na to, gdzie mieszkają, jakim językiem mówią i jakim posługują się kodem kulturowym. Nie dążę do tego, żeby każdy mógł zrozumieć przesłanie moich plakatów. To za mało w zabieganym, nieuważnym, pełnym uprzedzeń i stereotypów świecie. Ideałem jest dla mnie realizacja 
zalecenia Kwintyliana: „Należy dbać nie o to, aby [odbiorca] mógł zrozumieć, lecz o to, aby w ogóle nie mógł nie zrozumieć”. Twórca plakatu społecznego nie może liczyć na „wspomnienie wnuka” - albo zwróci uwagę odbiorcy i zmusi go do zatrwożenia, albo będzie „wołał na puszczy”. Wszystkie chwyty są dozwolone, ja wybieram własny język wizualny. Decydującymi elementami w doborze tematów jest dla mnie społeczeństwo i zmiany zachodzące. Technologia pozwala na przyspieszanie tych zmian na tyle szybko, że widać nierówny wyścig przyzwyczajania, a tym samym ogólnopojętej akceptacji do stanu rzeczy. Zbyt zmęczone społeczeństwo nie ma już czasu na kontemplację o bycie.

Dlatego uważam, że plakat może być najbardziej sensowną formą przekazu zmuszając do pobudzenia odbiorcy do przemyśleń. Dla mnie plakat jest najbardziej ludzką formą przekazu myśli w przestrzeni miejskiej. Wykorzystanie go do „walki ulicznej” o konkluzje społecznego bytu jest idealnym narzędziem, którym może posłużyć się projektant w dialogu z odbiorcą.

\section{BIBLIOGRAFIA}

Giżka, S. (2007). Polska Szkoła Plakatu. http://culture.pl/pl/artykul/polska-szkola-plakatu [dostęp: 24.06.2021].

Doroszewski, W. (red.). (online). Słownik języka polskiego. Warszawa: PWN. https://sjp.pwn. $\mathrm{pl} /$ doroszewski/plakat;5472446.html [dostęp: 24.06.2021].

Lenica, J. (1952). Plakat - sztuka dzisiejszych czasów. Przegląd Artystyczny, 5.

Lenica, J. (1958). Plakat Tadeusza Trepkowskiego. Warszawa: Wydawnictwo ArtystycznoGraficzne RSW „Prasa”. https://culture.pl/pl/artykul/polska-szkola-plakatu [dostęp: 24.06.2021].

\section{SUMMARY}

\section{Storytelling with a picture: author poster}

The aim of the article is to present the theoretical assumptions of the phenomenon that can be described as a "social poster". In the first part of the work, I describe the origins, sources and historical context of the creation and functioning of the so-called Polish School of Posters. It is a school which, at the turn of several decades of the last century, built the significance of the poster, not only as an artistic work (with a clearly visible aesthetic function), but also as a product with a strong social impact. The second part of the text is definitely more personal. In it, I present the subject of my posters as well as the events and impulses that prompted me to undertake it. For me, the decisive elements in the selection of topics are society and the changes taking place in it. And the poster is, in my opinion, the most human form of conveying thoughts in urban space, and at the same time an important voice in the "street fight".

KEYWORDS: social poster, social impact, poster as a form of expression. 